\title{
Jak-Stat Signaling Induced by Interleukin-6 Family Cytokines in Hepatocellular Carcinoma
}

\author{
Juliane Lokau ${ }^{1}$, Victor Schoeder ${ }^{1}$, Johannes Haybaeck ${ }^{1,2,3}$ and Christoph Garbers ${ }^{1, *}$ (i) \\ 1 Department of Pathology, Medical Faculty, Otto-von-Guericke-University Magdeburg, 39120 Magdeburg, \\ Germany; juliane.lokau@med.ovgu.de (J.L.); victor.schoeder@med.ovgu.de (V.S.); \\ johannes.haybaeck@med.ovgu.de (J.H.) \\ 2 Diagnostic \& Research Center for Molecular BioMedicine, Institute of Pathology, Medical University of Graz, \\ 8036 Graz, Austria \\ 3 Department of Pathology, Neuropathology, and Molecular Pathology, Medical University of Innsbruck, \\ 6020 Innsbruck, Austria \\ * Correspondence: christoph.garbers@med.ovgu.de; Tel.: +49-391-67-15488; Fax: +49-391-67-15818
}

Received: 15 October 2019; Accepted: 30 October 2019; Published: 1 November 2019

\begin{abstract}
Hepatocellular carcinoma (HCC) is one of the most common malignant tumors worldwide. It can be caused by chronic liver cell injury with resulting sustained inflammation, e.g., triggered by infections with hepatitis viruses B (HBV) and C (HCV). Death of hepatocytes leads to the activation of compensatory mechanisms, which can ultimately result in liver fibrosis and cirrhosis. Another common feature is the infiltration of the liver with inflammatory cells, which secrete cytokines and chemokines that act directly on the hepatocytes. Among several secreted proteins, members of the interleukin-6 (IL-6) family of cytokines have emerged as important regulatory proteins that might constitute an attractive target for therapeutic intervention. The IL-6-type cytokines activate multiple intracellular signaling pathways, and especially the Jak/STAT cascade has been shown to be crucial for HCC development. In this review, we give an overview about HCC pathogenesis with respect to IL-6-type cytokines and the Jak/STAT pathway. We highlight the role of mutations in genes encoding several proteins involved in the cytokine/Jak/STAT axis and summarize current knowledge about IL-6 family cytokines in this context. We further discuss possible anti-cytokine therapies for HCC patients in comparison to already established therapies.
\end{abstract}

Keywords: HCC; Jak1; STAT3; IL-6

\section{Introduction}

Hepatocellular carcinoma (HCC) is one of the most frequent malignant tumors worldwide. It ranks first among all liver tumors, which, in total, are one of most common entities related to the number of deaths after lung, colorectum and stomach cancer [1]. The underlying causes are manifold, but are usually caused by sustained inflammation, chronic damage to the liver, e.g., alcohol abuse or ingestion of liver-toxic compounds, or infections with hepatitis viruses B (HBV) and C (HCV). During these processes, hepatocytic injury leads to the activation of compensatory mechanisms, which can ultimately result in liver fibrosis and cirrhosis. The livers of HCC patients are often infiltrated with different types of inflammatory cells, depending on the pathogenic agent. Importantly, nonalcoholic steatohepatitis (NASH) is a rising cause of HCC [2], and it is estimated that its role in HCC development will further increase [1].

The Jak/STAT signaling cascade is a central signaling hub that can be activated by a plethora of cytokines, growth factors and hormones [3]. It controls different cellular processes, including cell division, proliferation and cell fate decision. It consists of seven mammalian STAT family members 
that act as transcription factors and are activated by four different Janus kinases [4]. Besides its ability to convert extracellular stimuli to intracellular changes in the gene expression profile of the cell, several mutations in central proteins of the Jak/STAT pathway are known that constitutively activate the pathway without the need of a stimulus from outside of the cell [5].

In this review article, we summarize the etiology and mechanisms of hepatocarcinogenesis and describe the currently known functional consequences of Jak/STAT signaling in HCC. We focus on the interleukin-6 (IL-6) family of cytokines as the extracellular activator of the signaling cascade and report the contribution of activating mutations. Furthermore, we discuss possible strategies for targeting the Jak/STAT pathway or certain extracellular cytokines in HCC therapy.

\section{Etiology and Development of Hepatocellular Carcinoma (HCC)}

HCC is by far the most frequent of all primary liver malignancies, making up for at least $75 \%$ of all of them. It is the sixth most common cancer and the fourth most cancer-related cause of death worldwide [6]. In the vast majority of cases, the development of the various subtypes of HCC can be attributed to a defined cause [7]. About $80 \%$ of all HCC patients have an associated cirrhotic liver [8].

The underlying reason is a chronically incorporated or constantly active hepatotoxic agent [9], e.g., viral infections (mostly hepatitis viruses types B and C [10-12]) or chronic alcohol abuse. The latter and lifestyle-associated metabolic disorders are held responsible for the development of most liver cancers, especially in the so-called Northern Hemisphere [13]. However, non-alcoholic causes are also known, e.g., in the context of metabolic syndrome [14,15] like diabetes mellitus and dismal nutrition $[13,16]$. In addition, numerous exogenous substances can initiate hepatocellular carcinogenesis, like fungal toxins such as aflatoxin B1, which is especially important in tropical and subtropical regions [17]. Besides these rather common noxae, suffering from inherited malady, e.g., haemochromatosis or glycogen storage diseases, are rather seldom but relevant triggers for HCC formation [9].

From the current state of knowledge, the development of HCC follows a cascade of increasing accumulation of genetic alterations $[18,19]$. Cirrhotic or non-cirrhotic parenchymal changes associated with chronic liver disease form the basis for the emergence of premalignant conditions leading to HCC $[18,19]$ (Figure 1). Notwithstanding, especially in non-cirrhotic liver disease like chronic hepatitis B, the de novo-cancerogenesis is a well-known phenomenon [8]. In the gradual progression from a hepatocyte to the clonal proliferation of malignant liver cells, the first step is thought to be the dysplastic focus-a microscopic lesion with little atypia [20]. This alteration directly leads to the dysplastic nodule, a lesion that is frequently identifiable by radiological criteria and confirmed by histology [21]. Low- and high-grade dysplastic nodules are defined over the existence of so-called small cell changes on the one hand and large cell changes on the other hand [22]. These changes remain present in manifested HCC as well. The most striking, but not the only, criterion to differentiate these two forms of alterations in a dysplastic nodule is the cell size in comparison to the pre-existing hepatocyte [23]. Discrimination between low- and high-grade dysplasia is mostly based on the overall structural appearance and the size variation between individual cells within the particular dysplastic nodule [24].

The malignant potential of low-grade dysplastic nodules remains unclear. In contrast, high-grade dysplastic nodules periodically evolve into highly differentiated HCC [25]. These tumors are called small and early HCC [23]. If they remain undiscovered and untreated, they are believed to progress [23]. Subsequently, a larger, potentially lower differentiated and even higher malignant lesion will expand. HCC are defined by broadened liver cell cords and loss of the original reticulum network. This progress will often culminate in intra- and afterwards, extrahepatic metastasis. At that particular stage, the prognosis is devastating [26].

An important subtype of HCC is the steatohepatitic subtype, which is defined by the presence of intratumoral steatosis and inflammation. It accounts for up to $20 \%$ of all HCCs and is the archetypical liver cancer on the background of fatty liver disease, either alcohol-driven (arisen in Alcoholic 
Steatohepatitis, ASH) or not (Non-Alcoholic Steatohepatitis, NASH) [27-29]. A key molecular feature of steatohepatitic HCC is the activation of the IL-6/JAK/STAT signaling pathway [30].

HCC is an example of an extremely heterogenous cancer entity that displays a wide variety of genetic and molecular alterations [31], including mutations in members of the IL-6/Jak/STAT signaling cascade (see Section 5 for more details). Furthermore, telomere shortening, early-occurring activation of TERT promoter (as driver gene incident, [32-34]) and cell-cycle checkpoint regulator inactivation [35], e.g., of p21 [36,37], are some events of gradually increasing genetic changes [38]. Because the treatment of HCC is still challenging (see Section 6 for further details), establishing targeted therapeutics could lead to a certain advance in disease control.
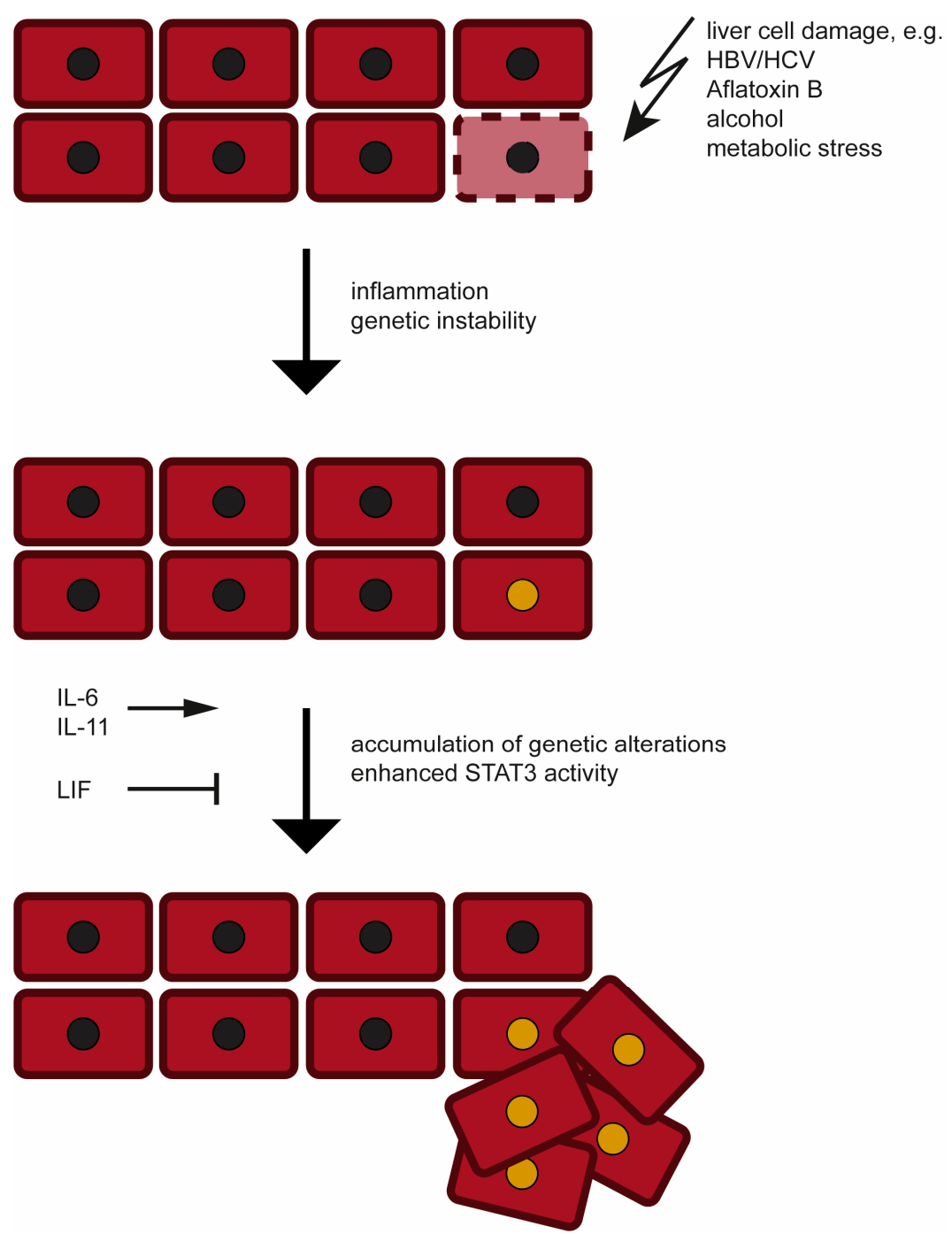

Figure 1. Schematic Depiction of HCC Development. Hepatocellular carcinogenesis is initiated by hepatocyte damage resulting in accumulation of genetic alterations and progression towards malignant liver cells. More details are given in the main text.

\section{The Jak/STAT Signaling Cascade}

One important family that activates the Jak/STAT signaling cascade is the interleukin-6 (IL-6) family of cytokines [39]. This family consists of IL-6, IL-11, IL-31, cardiotrophin-like cytokine (CLC), ciliary neurotrophic factor (CNTF), cardiotrophin-1 (CT-1), oncostatin M (OSM), leukemia inhibitory factor (LIF) and IL-27, which is a heterodimeric cytokine that consists of the two subunits EBI3 and p28 $[39,40]$. The hallmark of this family is the usage of the signal-transducing $\beta$-receptor gp130. IL-6 and IL-11 activate a gp130 homodimer and need an additional unique non-signaling $\alpha$-receptor 
(IL-6R and IL-11R) for complex formation [41]. CLC and CNTF bind first to the GPI-anchored CNTF receptor (CNTFR) before activating a heterodimer of gp130 and LIF receptor (LIFR). LIFR/gp130 are also activated by CT-1, OSM and LIF, but these three cytokines can engage their $\beta$-receptors directly and do not need an additional $\alpha$-receptor. OSM can furthermore signal via gp130 in combination with the OSM receptor (OSMR), and IL-27 activates a heterodimer of gp130 and WSX-1. The only exception is IL-31, which signals through a heterodimer of OSMR and gp130-like protein (GPL) [42].

Binding of IL-6-family cytokines to their cognate receptors induces homo- or heterodimerization of the signal transducing receptor glycoprotein (gp)130. This dimerization induces the activation of different intracellular signaling cascades, including PI3K/Akt-, MAPK-, Yap-cascade, and, most prominently, the Jak/STAT cascade $[39,43,44]$. The Jak/STAT pathway is a common signaling cascade that is shared by various cytokines and consists of four Jaks and seven STATs, albeit not all of them are equally involved in signal transduction for a specific extracellular molecule. Jak/STAT signaling is essential in numerous physiological processes and consequently involved in different diseases [4].

Gp130 is intracellularly constitutively associated with three members of Jak family, namely Jak1, Jak2, and Tyk2 [45]. The association of Jaks is dependent on two membrane-proximal motifs within the gp130 intracellular region: Box1 is a proline-rich sequence, while Box2 is a rather hydrophobic region [46-48]. Loss of either of these motifs prevents ligand-induced phosphorylation of gp130 [46]. Of the associated kinases, only Jak1 appears to be essential for gp130 signaling since genetic ablation of Jak1 severely reduces signaling of IL-6 family cytokines, while lack of Jak2 or Tyk2 had no substantial impact [49-52]. The binding of cytokines to their receptors results in an altered intracellular architecture [53], which brings the Jak kinases into close proximity, resulting in their autophosphorylation and activation [45]. The activated kinases then phosphorylate distinct tyrosine residues in the intracellular part of gp130, which serve as docking sites for STATs [54,55]. Mutational analysis revealed that STAT3 interacts with the four membrane-distal tyrosine residues pTyr767, pTyr814, pTyr905, and pTyr915, while STAT1 only binds to pTyr905 and pTyr915 [54,55]. Upon binding of the transcription factors to the phosphorylated gp130, STAT1/3 are also phosphorylated by Jak kinases, and thus activated [56]. Furthermore, STAT5 is also activated upon gp130 activation, albeit to a lesser extent. In contrast to STAT1/3, however, STAT5 does not bind to the phosphorylated gp130 but rather, interacts directly with the Jak kinases [57]. STAT1 and STAT3 are phosphorylated at Tyr701 and Tyr705, respectively [58], while activated STAT5 is phosphorylated at Tyr694 [59]. Phosphorylation of STATs results in dissociation from the receptor and reorientation in active homo- or heterodimers, which regulate the transcription of target genes [56,60,61] (Figure 2).

One of the target genes is the suppressor of cytokine signaling 3 (SOCS3), the main negative regulator of gp130-mediated signaling [62,63]. SOCS3 binds to phosphorylated Tyr759 in gp130 [64,65] and thus inactivates signaling via two distinct mechanisms. Firstly, it directly inhibits Jak activity through binding of its kinase inhibitory region to the kinase domain of Jak1, Jak2, or Tyk2, which prevents further phosphorylation of STATs [66-68]. Further, through binding to gp130 and Jak, SOCS3 promotes the proteosomal degradation of these molecules $[65,69,70]$. The Tyr759 residue is also the binding interface for another negative regulator, namely Src-homology-2-domain-containing phosphatase 2 (SHP2) [54,64,71,72]. In contrast to SOCS3, SHP2 does not represent a feedback inhibition but is constitutively expressed and interacts with gp130 directly upon phosphorylation of the receptor, thus rather regulating intensity than length of STAT activity $[47,73]$. Of note, SHP2 does not only act as negative regulator for STATs, but is also phosphorylated upon gp130 activation and subsequently, activates the PI3K and MAPK signaling cascades [43]. Another negative regulator of gp130 signaling is protein inhibitor of activated STAT (PIAS), which binds to phosphorylated STATs, thus preventing binding of the transcription factors to DNA [74,75]. 


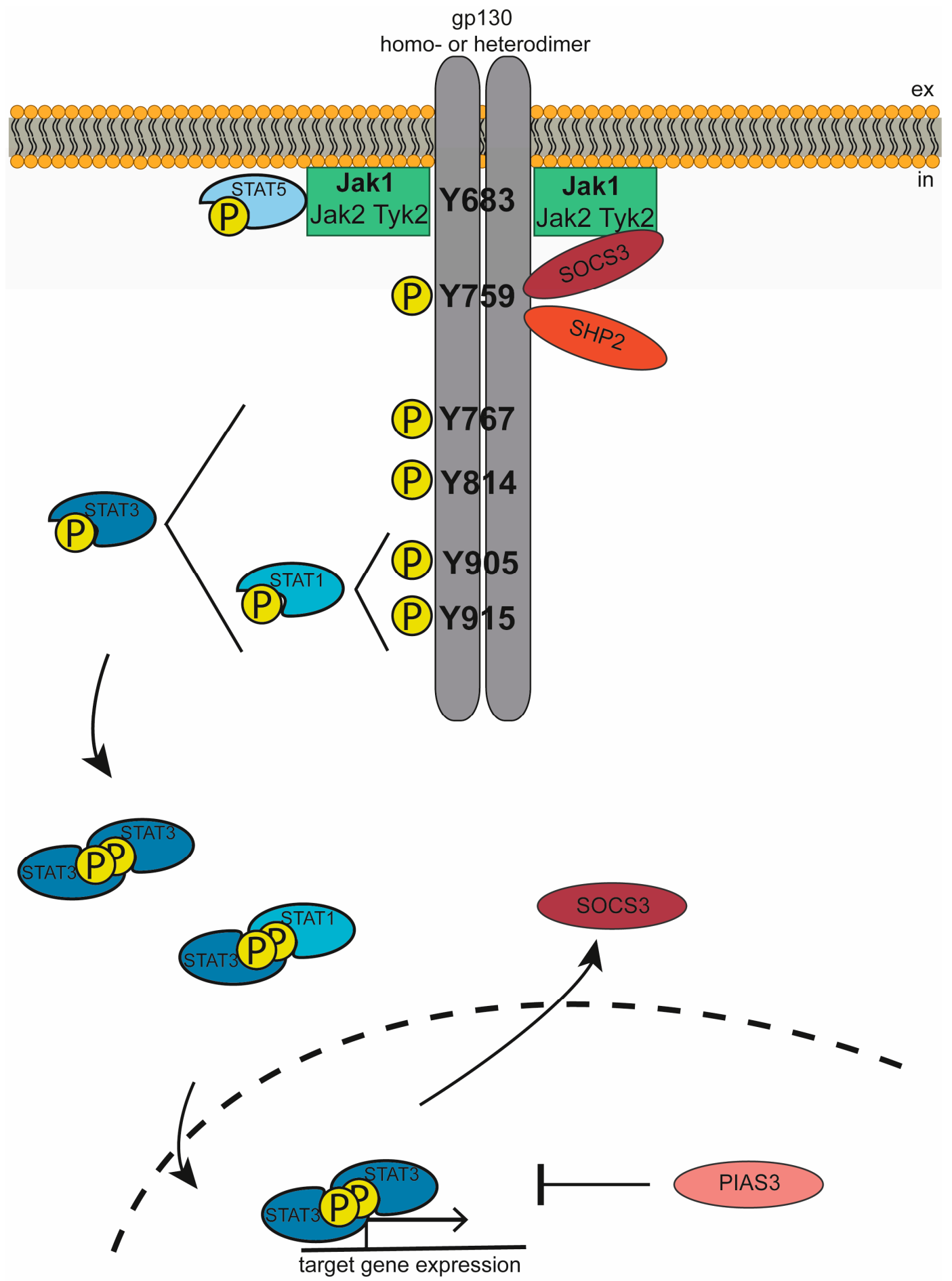

Figure 2. gp130-Mediated Jak/STAT Signaling. Upon cytokine binding, gp130 forms active homo-or heterodimers. This results in activation of intracellularly associated Janus kinases, which subsequently phosphorylate gp130 and STAT transcription factors, resulting in expression of target genes. Jak/STAT signaling is negatively regulated by SOCS3, PIAS3, and SHP2. More details are given in the main text.

\section{IL-6 Family Cytokines in HCC Development}

The best-characterized member of the IL-6 family of cytokines in HCC is IL-6 itself, with a large body of data from human patients and corresponding experimental mouse models. Evidence for increased IL-6 levels in chronic liver diseases has already been described more than 25 years ago [76-78]. Most recently, a systematic review and meta-analysis confirmed elevated IL-6 serum levels in HCC 
patients compared to healthy controls, and showed that HCC patients had even higher IL-6 levels than patients with other chronic liver diseases like cirrhosis or hepatitis [79]. Furthermore, high IL-6 levels might be associated with poor prognosis of patients with advanced HCC [80]. Also, the fact that HCC occurs mainly in men has been causatively linked to IL-6, because estrogen inhibits the release of IL-6 from Kupffer cells, which reduces the risk of developing HCC in women [81]. An important cellular source of IL-6 appear to be the tumor-associated macrophages [82], although HCC cells themselves are also able to secrete IL-6 in a YAP-dependent manner [83].

Interestingly, the amount of sIL-6R in the circulation of HCC patients is also increased, suggesting a possible role for IL-6 trans-signaling in this process [84]. This is further supported by experiments in mice overexpressing the IL-6 trans-signaling inhibitor $\operatorname{sgp} 130 \mathrm{Fc}$, which show reduced tumor formation in the diethylnitrosamine/3,3' ,5, $5^{\prime}$-tetrachloro-1,4-bis(pyridyloxy)benzene model of HCC [85].

Besides IL-6, IL-11 has also been implicated in hepatocarcinogenesis. IL-11 expression has been demonstrated in the tumor tissue, and this expression pattern correlated with higher tumor node metastasis stage and was shown to be a prognostic factor for overall survival [86]. Intratumoral IL-11 expression was also identified as a prognostic factor for the development of bone metastasis $[87,88]$. Mechanistically, a long noncoding RNA activated by TGF- $\beta$ (lncRNA-ATB) that is upregulated in HCC and is able to induce the epithelial-mesenchymal transition binds to the IL-11 mRNA and triggers STAT3 signaling through the autocrine induction of IL-11 production [89]. In addition, the long noncoding RNA Lnc34a is also overexpressed in HCC tissue and has a pro-metastatic function, at least partly by altering the TGF- $\beta$-induced IL-11 expression [90]. Recently, transmembrane p24 trafficking protein 3 (TMED3) has been shown to be upregulated in HCC and to be associated with poor prognosis for the patients. TMED3 appears to increase IL-11 expression and thereby promote HCC metastasis [91]. However, the involvement of TGF- $\beta$ was not investigated and it is, therefore, unclear whether TMED3 and TGF- $\beta$ independently promote IL-11 expression in HCC, or whether they are part of the same molecular pathway. Most recently, Wang and colleagues investigated possible mechanisms that underlie the risk of HCC recurrence after surgery [92]. They identify IL-11 as a key factor that increases after surgery and show that blocking of STAT3 signaling induced by IL-11 reduces proliferation of the tumor cells and, eventually, HCC [92].

The third well-characterized family member is LIF. LIF was shown to be highly expressed in HCC tumor samples [93]. Its expression was inversely associated with the microRNA miR-637, which was downregulated in HCC specimen and different HCC cell lines. Mechanistically, overexpression of mimics of miR-637 decreased STAT3 phosphorylation in HCC cell lines by suppressing the autocrine production of LIF [93]. LIFR expression has further been proposed as a biomarker for the differentiation of HCC from dysplastic nodules, showing that LIFR expression decreases as the tumor cells progress from low-grade dysplastic nodules to HCC [94]. Indeed, LIFR has been previously described as an HCC tumor suppressor gene that is silenced in HCC due to hypermethylation of the promotor of the LIFR gene [95]. This finding was later substantiated in a study showing that LIFR expression is not only reduced in HCC, but even further downregulated in HCC with metastasis [96].

Six- to seven-fold increased levels of OSM were detected in the serum of HCC patients compared to controls [97]. Similarly, serum levels of IL-27 were significantly increased in HCC patients compared to either healthy control patients or patients with other liver diseases like cirrhosis or hepatitis [98]. In contrast, a recent report showed decreased expression of EBI3, which is the subunit of IL-27 that resembles a soluble cytokine receptor, in HCC, which was associated with poor prognosis [99]. However, no functional role for these two cytokines has been established in HCC, and elevated serum levels might not be causatively linked to HCC. The role of the other members of the IL-6 family of cytokines in HCC is even less clear, with the exception of IL-31, which was reported to be largely absent in the serum of HCC patients [100].

Although the mechanisms of how IL-6-family cytokines induce HCC development are not entirely understood, the activation of the STAT3 signaling pathway, which is a hallmark of these cytokines, appears to be the underlying molecular cause. 


\section{Inborn Mutations in Proteins of the Jak/STAT Cascade in HCC Development}

Various mutations and genetic alterations have been described to be involved in the onset and progression of HCC [101-103], and it has been reported that histological subtypes correlate with specific mutations [30]. According to Kan et al. and Nault et al., 45.5\% of HCC patients display altered Jak/STAT signaling $[33,104]$, although it must be noted that not all of these mutations are found in gp130-associated molecules.

Activating mutations in gp130 are found in 1-2\% of HCC patients [105]. Mechanistically, the mutated receptors harbor small in-frame deletions in the cytokine binding site, which results in ligand-independent phosphorylation of STAT3 [105]. Notably, the mutated gp130 variants remain responsive towards inhibition by SOCS3 [106]. Furthermore, it could be shown that the phosphorylation of STAT3 was solely mediated by Jak1, but not Jak2 or Tyk2 [106]. Interestingly, these activating gp130 mutations are much more frequent in inflammatory hepatocellular adenomas (iHCA) than in HCC [105]. Furthermore, gp130 mutations accompanied by $\beta$-catenin mutations appear to promote malignant transformation of iHCAs [105]. Interestingly, in a mouse model for HCC, lack of gp130 in hepatocytes did not prevent initiation of HCC but attenuated cancer progression [107].

For the $\alpha$-receptors of the IL-6 family, no mutations have been directly linked to HCC. However, several variants of these receptors are found in humans, which might affect HCC development in homozygous carriers. The frequent single-nucleotide polymorphism (SNP) rs2228145 in the IL-6R results in an exchange from Asp358 to Ala358 [108,109]. This IL-6R variant is much more prone towards proteolytic processing [110], resulting in an increase in circulating soluble IL-6R and a decrease in IL-6R amount on hepatocytes, thus an attenuated IL-6 response $[108,109,111]$. Furthermore, there are inactivating mutations in the IL-11R that results in loss of surface IL-11R and consequently in cells unresponsive towards IL-11 [112-114]. Carriers of these mutations would also not have any IL-11 response in hepatocytes.

Different point mutations in Jak1 have been described in HCC patients, which are predominantly located in the kinase and pseudokinase domains $[104,115,116]$. Notably, the majority of these mutations result in increased phosphorylation of Jak1 and STAT3 without stimulus. In contrast, IL-6-dependent Jak/STAT signaling was not altered with the Jak1 variants compared to wildtype Jak1 [104]. Most of the activating mutants are located at the pseudokinase/kinase domain interface and hypothesized to interfere with this interaction, thus preventing the inhibitory effect of the pseudokinase domain [104]. A similar mechanism has been proposed for the well-studied Jak2 mutant V617F [117]. Importantly, some of the Jak1 mutations that were identified in HCC patients showed no functional difference from wildtype Jak1 in vitro $[104,116]$. It has recently been proposed that the mutational status of Jak1 could be used to predict the efficacy of Jak1 inhibitors for treatment of HCC [116].

While STAT3 is phosphorylated in $60 \%$ of human HCC and active STAT3 correlates with tumor aggressiveness $[118,119]$, no patients harboring STAT3 mutations have been described. However, activating STAT3 mutations have been described in iHCA patients [120]. These mutations are predominantly, but not exclusively, found in the SH2 domain of STAT3 and result in ligand-independent dimerization and Tyr705 phosphorylation of STAT3 and, consequently, in DNA binding and target gene expression $[120,121]$. Of note, mice that lack STAT3 expression in hepatocytes are protected from HCC [118]. Furthermore, the long noncoding RNA TSLNC8, which inhibits the phosphorylation of STAT3, is frequently downregulated in HCC patients. This RNA correlated with lower differentiation and patients with low expression of this RNA exhibited poorer survival [122].

In contrast to the tumor-promoting function of STAT3, there are indications that STAT1 might have rather tumor-suppressive effects [123,124]. In HCC patients, the majority of STAT1 is unphosphorylated, while phosphorylated STAT1 is responsible for the anti-tumor effect [125]. No STAT1 mutations have been described to correlate with HCC.

No mutations in the coding sequence of SOCS3 are reported in HCC patients, but the promoter region is frequently hypermethylated, accompanied by reduced protein expression, which presumably contributes to the increase in STAT3 phosphorylation [126]. SOCS3 is downregulated specifically in 
HCC patients with a poor prognosis $[119,127]$ and might be used as a marker to predict treatment response [128]. Expectedly, mice with a hepatocyte-specific SOCS3 deletion are more sensitive towards chemically induced HCC [129].

\section{Therapeutic Opportunities for HCC Patients}

Currently, several different treatment options exist for HCC patients (more detailed information can be found in recent reviews, e.g., [1,130-132]). An important therapy is the surgical resection of the tumor, although this is only indicated in patients in which hepatic function is preserved after partial hepatectomy and important co-morbidities of the patient like portal hypertension must be considered [21]. Other treatment options are local tumor ablation and transarterial therapies, in which transarterial chemoembolization (TACE) is the main method of choice [1]. TACE works by the infusion of chemotherapeutic agents coupled to embolic particles directly into an artery that is part of the tumors' blood supply, thereby not only targeting the tumor cells by chemotherapy, but simultaneously reducing the oxygen provision of the HCC. A recent systematic review reported an objective response rate of $52.5 \%$ when HCC patients were treated with TACE [133]. Interestingly, there is also recent evidence that the serum levels of the cytokines IL- 6 and IL- 8 can be used as biomarkers to predict not only the tumor response, but also the overall survival after TACE [134].

The IL-6/Jak/STAT signaling axis offers multiple points for therapeutic intervention $[135,136]$. Best studied in this regard is IL-6 itself, which has been identified as a key therapeutic target in practically all inflammatory diseases [135]. Inhibitory antibodies against IL-6 or the IL-6R receptor are either already clinically approved or are in late-stage clinical development for different diseases, including rheumatoid arthritis, Castleman disease and cytokine release syndrome [135]. As mentioned above, sgp130Fc, which is also named Olamkicept and currently tested in phase II clinical trials in IBD patients, led to reduced tumor numbers in a mouse model of HCC and might, therefore, be a possible therapeutic opportunity [85]. However, mice with a hepatocyte-specific deletion gp130, the signal-transducing receptor of all cytokines of the IL-6 family, showed reduced progression, but no alteration in HCC initiation in the DEN model [107]. Whether targeting IL-6, IL-11 or one of the other family members has therapeutic value for human patients is currently unclear, but one might argue that inhibition of IL-6 might not be a suitable primary treatment option, but could be combined with one of the therapies outlined above. Nevertheless, a phase I/Ib study with AZD9150 (ISIS481464), an antisense oligonucleotide targeting STAT3, has been performed in 58 patients with advanced/metastatic HCC (ClinicalTrials.gov Identifier: NCT01839604). The drug appears to be tolerable, with serious adverse effects in four out of 15 patients that received the highest dose of $3 \mathrm{mg} / \mathrm{kg}$ body weight.

HCC patients can further be treated with systemic drugs. The multi kinase inhibitor sorafenib, which targets several kinases including c-Raf, VEGFR and PDGFR, was the first one that was approved by the FDA to treat HCC [1]. In a multicenter, phase 3, double-blind, placebo-controlled trial, the median overall survival was significantly higher for patients treated with sorafenib (10.7 months) compared to placebo (7.9 months) [137]. A number of other systemic drugs failed in clinical trials. However, most recently, lenvatinib, another multi kinase inhibitor that targets VEGFR1, 2 and 3, FGFR1, 2, 3 and 4, KIT, RET and PDGFR $\alpha$, showed non-inferiority towards sorafenib in terms of median survival time (13.6 months vs. 12.3 months) [138]. Whether Janus kinase inhibitors, which are clinically approved for different inflammatory and immune diseases [139], could also be beneficial as a therapy in HCC is not known. At least in vitro, the Jak inhibitor ruxolitinib reduced proliferation and colony formation of HCC cells [140]. There is also anecdotal evidence from a variety of other small molecules that are presumably able to block the IL-6/Jak/STAT signaling axis, e.g., bazedoxifene, which is currently approved as a selective estrogen receptor modulator (SERM) [141]. It is currently unclear if and when such approaches will translate into the clinics. 


\section{Conclusions}

Liver cancer, including HCC, is one of the leading causes of cancer-related deaths worldwide. Although progress has been achieved in the therapy and management of HCC patients, new additional approaches are warranted nevertheless.

Cytokines activating the Jak/STAT signaling cascade have been implicated in HCC initiation and development, and in particular IL-6 and IL-11 show encouraging results not only as potential biomarkers for liver tumors, but also as functional therapeutic targets. Initial studies demonstrating that blocking IL-6 or IL-11 in HCC reduces tumor burden in mice have recently been published [85,92], and these encouraging first results now must be confirmed and translated into the clinic. It is tempting to speculate that these cytokines also play important roles in other tumor entities of the liver. The same holds true for other proteins involved in IL-6 signaling like the metalloprotease ADAM17, which is not only recently identified and proposed as a target in lung cancer [142,143], but has also been implicated in HCC, where higher ADAM17 expression and the resulting activation of the receptor Notch1 correlated with poor prognosis of the patients [144].

In summary, targeting cytokines and, in particular, the Jak/STAT signaling cascade might be a useful therapeutic option for patients suffering from HCC.

Author Contributions: J.L., V.S. and C.G. wrote and edited the manuscript, and J.H. edited the manuscript.

Funding: Work in the lab of C.G. is funded by the Deutsche Forschungsgemeinschaft (DFG, German Research Foundation)—Projektnummer 125440785-SFB 877 (projects A10 and A14).

Conflicts of Interest: C.G. has received funding support from Corvidia Therapeutics (Waltham, MA, USA). Others declare no conflicts of interest.

\section{References}

1. Villanueva, A. Hepatocellular Carcinoma. N. Engl. J. Med. 2019, 380, 1450-1462. [CrossRef] [PubMed]

2. Younossi, Z.; Stepanova, M.; Ong, J.P.; Jacobson, I.M.; Bugianesi, E.; Duseja, A.; Eguchi, Y.; Wong, V.W.; Negro, F.; Yilmaz, Y.; et al. Nonalcoholic Steatohepatitis Is the Fastest Growing Cause of Hepatocellular Carcinoma in Liver Transplant Candidates. Clin. Gastroenterol Hepatol. 2019, 17, 748-755.e743. [CrossRef] [PubMed]

3. Villarino, A.V.; Kanno, Y.; O'Shea, J.J. Mechanisms and consequences of Jak-STAT signaling in the immune system. Nat. Immunol. 2017, 18, 374-384. [CrossRef] [PubMed]

4. O'Shea, J.J.; Schwartz, D.M.; Villarino, A.V.; Gadina, M.; McInnes, I.B.; Laurence, A. The JAK-STAT pathway: Impact on human disease and therapeutic intervention. Annu. Rev. Med. 2015, 66, 311-328. [CrossRef] [PubMed]

5. Lokau, J.; Garbers, C. Activating mutations of the gp130/JAK/STAT pathway in human diseases. Adv. Protein Chem. Struct. Biol. 2019, 116, 283-309. [CrossRef] [PubMed]

6. Bray, F.; Ferlay, J.; Soerjomataram, I.; Siegel, R.L.; Torre, L.A.; Jemal, A. Global cancer statistics 2018: GLOBOCAN estimates of incidence and mortality worldwide for 36 cancers in 185 countries. CA Cancer J. Clin. 2018, 68, 394-424. [CrossRef] [PubMed]

7. Global Burden of Disease Liver Cancer Collaboration; Akinyemiju, T.; Abera, S.; Ahmed, M.; Alam, N.; Alemayohu, M.A.; Allen, C.; Al-Raddadi, R.; Alvis-Guzman, N.; Amoako, Y.; et al. The Burden of Primary Liver Cancer and Underlying Etiologies from 1990 to 2015 at the Global, Regional, and National Level: Results from the Global Burden of Disease Study 2015. JAMA Oncol. 2017, 3, 1683-1691. [CrossRef]

8. Degasperi, E.; Colombo, M. Distinctive features of hepatocellular carcinoma in non-alcoholic fatty liver disease. Lancet Gastroenterol. Hepatol. 2016, 1, 156-164. [CrossRef]

9. Sanyal, A.J.; Yoon, S.K.; Lencioni, R. The etiology of hepatocellular carcinoma and consequences for treatment. Oncologist 2010, 15 (Suppl. 4), 14-22. [CrossRef]

10. Raimondi, S.; Bruno, S.; Mondelli, M.U.; Maisonneuve, P. Hepatitis C virus genotype $1 \mathrm{~b}$ as a risk factor for hepatocellular carcinoma development: A meta-analysis. J. Hepatol. 2009, 50, 1142-1154. [CrossRef] 
11. Kanwal, F.; Kramer, J.R.; Ilyas, J.; Duan, Z.; El-Serag, H.B. HCV genotype 3 is associated with an increased risk of cirrhosis and hepatocellular cancer in a national sample of U.S. Veterans with HCV. Hepatology 2014, 60, 98-105. [CrossRef] [PubMed]

12. Wang, Q.; Luan, W.; Villanueva, G.A.; Rahbari, N.N.; Yee, H.T.; Manizate, F.; Hiotis, S.P. Clinical prognostic variables in young patients (under 40 years) with hepatitis B virus-associated hepatocellular carcinoma. J. Dig. Dis. 2012, 13, 214-218. [CrossRef] [PubMed]

13. Paradis, V.; Zalinski, S.; Chelbi, E.; Guedj, N.; Degos, F.; Vilgrain, V.; Bedossa, P.; Belghiti, J. Hepatocellular carcinomas in patients with metabolic syndrome often develop without significant liver fibrosis: A pathological analysis. Hepatology 2009, 49, 851-859. [CrossRef]

14. Schlesinger, S.; Aleksandrova, K.; Pischon, T.; Jenab, M.; Fedirko, V.; Trepo, E.; Overvad, K.; Roswall, N.; Tjonneland, A.; Boutron-Ruault, M.C.; et al. Diabetes mellitus, insulin treatment, diabetes duration, and risk of biliary tract cancer and hepatocellular carcinoma in a European cohort. Ann. Oncol. 2013, 24, 2449-2455. [CrossRef] [PubMed]

15. Calle, E.E.; Rodriguez, C.; Walker-Thurmond, K.; Thun, M.J. Overweight, obesity, and mortality from cancer in a prospectively studied cohort of U.S. adults. N. Engl. J. Med. 2003, 348, 1625-1638. [CrossRef] [PubMed]

16. Lee, T.Y.; Wu, J.C.; Yu, S.H.; Lin, J.T.; Wu, M.S.; Wu, C.Y. The occurrence of hepatocellular carcinoma in different risk stratifications of clinically noncirrhotic nonalcoholic fatty liver disease. Int. J. Cancer 2017, 141, 1307-1314. [CrossRef] [PubMed]

17. Chu, Y.J.; Yang, H.I.; Wu, H.C.; Lee, M.H.; Liu, J.; Wang, L.Y.; Lu, S.N.; Jen, C.L.; You, S.L.; Santella, R.M.; et al. Aflatoxin B1 exposure increases the risk of hepatocellular carcinoma associated with hepatitis $C$ virus infection or alcohol consumption. Eur. J. Cancer 2018, 94, 37-46. [CrossRef]

18. Seshachalam, V.P.; Sekar, K.; Hui, K.M. Insights into the etiology-associated gene regulatory networks in hepatocellular carcinoma from The Cancer Genome Atlas. J. Gastroenterol. Hepatol. 2018, 33, 2037-2047. [CrossRef]

19. Moinzadeh, P.; Breuhahn, K.; Stutzer, H.; Schirmacher, P. Chromosome alterations in human hepatocellular carcinomas correlate with aetiology and histological grade-Results of an explorative CGH meta-analysis. Br. J. Cancer 2005, 92, 935-941. [CrossRef]

20. The International Consensus Group for Hepatocellular Neoplasia. Pathologic diagnosis of early hepatocellular carcinoma: A report of the international consensus group for hepatocellular neoplasia. Hepatology 2009, 49, 658-664. [CrossRef]

21. European Association for the Study of the Liver. EASL Clinical Practice Guidelines: Management of hepatocellular carcinoma. J. Hepatol. 2018, 69, 182-236. [CrossRef] [PubMed]

22. Park, Y.N. Update on precursor and early lesions of hepatocellular carcinomas. Arch. Pathol. Lab. Med. 2011, 135, 704-715. [CrossRef]

23. Roncalli, M.; Terracciano, L.; Di Tommaso, L.; David, E.; Colombo, M.; Gruppo Italiano Patologi Apparato Digerente (GIPAD); Società Italiana di Anatomia Patologica e Citopatologia Diagnostica/International Academy of Pathology, Italian division (SIAPEC/IAP). Liver precancerous lesions and hepatocellular carcinoma: The histology report. Dig. Liver Dis. 2011, 43 (Suppl. 4), S361-S372. [CrossRef]

24. Niu, Z.S.; Niu, X.J.; Wang, W.H.; Zhao, J. Latest developments in precancerous lesions of hepatocellular carcinoma. World J. Gastroenterol. 2016, 22, 3305-3314. [CrossRef] [PubMed]

25. Sato, T.; Kondo, F.; Ebara, M.; Sugiura, N.; Okabe, S.; Sunaga, M.; Yoshikawa, M.; Suzuki, E.; Ogasawara, S.; Shinozaki, Y.; et al. Natural history of large regenerative nodules and dysplastic nodules in liver cirrhosis: 28-year follow-up study. Hepatol. Int. 2015, 9, 330-336. [CrossRef]

26. Tandon, P.; Garcia-Tsao, G. Prognostic indicators in hepatocellular carcinoma: A systematic review of 72 studies. Liver Int. 2009, 29, 502-510. [CrossRef]

27. Salomao, M.; Remotti, H.; Vaughan, R.; Siegel, A.B.; Lefkowitch, J.H.; Moreira, R.K. The steatohepatitic variant of hepatocellular carcinoma and its association with underlying steatohepatitis. Hum. Pathol. 2012, 43, 737-746. [CrossRef]

28. Shibahara, J.; Ando, S.; Sakamoto, Y.; Kokudo, N.; Fukayama, M. Hepatocellular carcinoma with steatohepatitic features: A clinicopathological study of Japanese patients. Histopathology 2014, 64, 951-962. [CrossRef] 
29. Jain, D.; Nayak, N.C.; Kumaran, V.; Saigal, S. Steatohepatitic hepatocellular carcinoma, a morphologic indicator of associated metabolic risk factors: A study from India. Arch. Pathol. Lab. Med. 2013, 137, 961-966. [CrossRef]

30. Calderaro, J.; Couchy, G.; Imbeaud, S.; Amaddeo, G.; Letouze, E.; Blanc, J.F.; Laurent, C.; Hajji, Y.; Azoulay, D.; Bioulac-Sage, P.; et al. Histological subtypes of hepatocellular carcinoma are related to gene mutations and molecular tumour classification. J. Hepatol. 2017, 67, 727-738. [CrossRef]

31. Cancer Genome Atlas Research Network. Comprehensive and Integrative Genomic Characterization of Hepatocellular Carcinoma. Cell 2017, 169, 1327-1341 e1323. [CrossRef] [PubMed]

32. Nault, J.C.; Mallet, M.; Pilati, C.; Calderaro, J.; Bioulac-Sage, P.; Laurent, C.; Laurent, A.; Cherqui, D.; Balabaud, C.; Zucman-Rossi, J. High frequency of telomerase reverse-transcriptase promoter somatic mutations in hepatocellular carcinoma and preneoplastic lesions. Nat. Commun. 2013, 4, 2218. [CrossRef] [PubMed]

33. Nault, J.C.; Calderaro, J.; Di Tommaso, L.; Balabaud, C.; Zafrani, E.S.; Bioulac-Sage, P.; Roncalli, M.; Zucman-Rossi, J. Telomerase reverse transcriptase promoter mutation is an early somatic genetic alteration in the transformation of premalignant nodules in hepatocellular carcinoma on cirrhosis. Hepatology 2014, 60, 1983-1992. [CrossRef] [PubMed]

34. Torrecilla, S.; Sia, D.; Harrington, A.N.; Zhang, Z.; Cabellos, L.; Cornella, H.; Moeini, A.; Camprecios, G.; Leow, W.Q.; Fiel, M.I.; et al. Trunk mutational events present minimal intra-and inter-tumoral heterogeneity in hepatocellular carcinoma. J. Hepatol. 2017, 67, 1222-1231. [CrossRef] [PubMed]

35. Lee, Y.H.; Oh, B.K.; Yoo, J.E.; Yoon, S.M.; Choi, J.; Kim, K.S.; Park, Y.N. Chromosomal instability, telomere shortening, and inactivation of p21(WAF1/CIP1) in dysplastic nodules of hepatitis B virus-associated multistep hepatocarcinogenesis. Mod. Pathol. 2009, 22, 1121-1131. [CrossRef] [PubMed]

36. Plentz, R.R.; Park, Y.N.; Lechel, A.; Kim, H.; Nellessen, F.; Langkopf, B.H.; Wilkens, L.; Destro, A.; Fiamengo, B.; Manns, M.P.; et al. Telomere shortening and inactivation of cell cycle checkpoints characterize human hepatocarcinogenesis. Hepatology 2007, 45, 968-976. [CrossRef] [PubMed]

37. Marchio, A.; Terris, B.; Meddeb, M.; Pineau, P.; Duverger, A.; Tiollais, P.; Bernheim, A.; Dejean, A. Chromosomal abnormalities in liver cell dysplasia detected by comparative genomic hybridisation. Mol. Pathol. 2001, 54, 270-274. [CrossRef] [PubMed]

38. Marquardt, J.U.; Seo, D.; Andersen, J.B.; Gillen, M.C.; Kim, M.S.; Conner, E.A.; Galle, P.R.; Factor, V.M.; Park, Y.N.; Thorgeirsson, S.S. Sequential transcriptome analysis of human liver cancer indicates late stage acquisition of malignant traits. J. Hepatol. 2014, 60, 346-353. [CrossRef] [PubMed]

39. Garbers, C.; Hermanns, H.; Schaper, F.; Müller-Newen, G.; Grötzinger, J.; Rose-John, S.; Scheller, J. Plasticity and cross-talk of Interleukin 6-type cytokines. Cytokine Growth Factor Rev. 2012, 23, 85-97. [CrossRef]

40. Aparicio-Siegmund, S.; Garbers, C. The biology of interleukin-27 reveals unique pro-and anti-inflammatory functions in immunity. Cytokine Growth Factor Rev. 2015, 26, 579-586. [CrossRef]

41. Garbers, C.; Scheller, J. Interleukin-6 and interleukin-11: Same same but different. Biol. Chem. 2013, 394, 1145-1161. [CrossRef] [PubMed]

42. Hermanns, H.M. Oncostatin $M$ and interleukin-31: Cytokines, receptors, signal transduction and physiology. Cytokine Growth Factor Rev. 2015, 26, 545-558. [CrossRef] [PubMed]

43. Eulenfeld, R.; Dittrich, A.; Khouri, C.; Muller, P.J.; Mutze, B.; Wolf, A.; Schaper, F. Interleukin-6 signalling: More than Jaks and STATs. Eur. J. Cell Biol. 2012, 91, 486-495. [CrossRef] [PubMed]

44. Taniguchi, K.; Wu, L.-W.; Grivennikov, S.I.; de Jong, P.R.; Lian, I.; Yu, F.-X.; Wang, K.; Ho, S.B.; Boland, B.S.; Chang, J.T.; et al. A gp130-Src-YAP module links inflammation to epithelial regeneration. Nature 2015, 519, 57-62. [CrossRef] [PubMed]

45. Stahl, N.; Boulton, T.G.; Farruggella, T.; Ip, N.Y.; Davis, S.; Witthuhn, B.A.; Quelle, F.W.; Silvennoinen, O.; Barbieri, G.; Pellegrini, S.; et al. Association and activation of Jak-Tyk kinases by CNTF-LIF-OSM-IL-6 beta receptor components. Science 1994, 263, 92-95. [CrossRef] [PubMed]

46. Murakami, M.; Narazaki, M.; Hibi, M.; Yawata, H.; Yasukawa, K.; Hamaguchi, M.; Taga, T.; Kishimoto, T. Critical cytoplasmic region of the interleukin 6 signal transducer gp130 is conserved in the cytokine receptor family. Proc. Natl. Acad. Sci. USA 1991, 88, 11349-11353. [CrossRef] [PubMed]

47. Morris, R.; Kershaw, N.J.; Babon, J.J. The molecular details of cytokine signaling via the JAK/STAT pathway. Protein Sci. 2018, 27, 1984-2009. [CrossRef] [PubMed] 
48. Greiser, J.S.; Stross, C.; Heinrich, P.C.; Behrmann, I.; Hermanns, H.M. Orientational constraints of the gp130 intracellular juxtamembrane domain for signaling. J. Biol. Chem. 2002, 277, 26959-26965. [CrossRef]

49. Guschin, D.; Rogers, N.; Briscoe, J.; Witthuhn, B.; Watling, D.; Horn, F.; Pellegrini, S.; Yasukawa, K.; Heinrich, P.; Stark, G. A major role for the protein tyrosine kinase JAK1 in the JAK/STAT signal transduction pathway in response to interleukin-6. EMBO J. 1995, 14, 1421-1429. [CrossRef]

50. Rodig, S.J.; Meraz, M.A.; White, M.J.; Lampe, P.A.; Riley, J.K.; Arthur, C.D.; King, K.L.; Sheehan, K.C.F.; Yin, L.; Pennica, D.; et al. Disruption of the Jak1 Gene Demonstrates Obligatory and Nonredundant Roles of the Jaks in Cytokine-Induced Biologic Responses. Cell 1998, 93, 373-383. [CrossRef]

51. Schaper, F.; Gendo, C.; Eck, M.; Schmitz, J.; Grimm, C.; Anhuf, D.; Kerr, I.; Heinrich, P. Activation of the protein tyrosine phosphatase SHP2 via the interleukin-6 signal transducing receptor protein gp130 requires tyrosine kinase Jak1 and limits acute-phase protein expression. Biochem. J. 1998, 335, 557-565. [CrossRef] [PubMed]

52. Karaghiosoff, M.; Neubauer, H.; Lassnig, C.; Kovarik, P.; Schindler, H.; Pircher, H.; McCoy, B.; Bogdan, C.; Decker, T.; Brem, G.; et al. Partial impairment of cytokine responses in Tyk2-deficient mice. Immunity 2000, 13, 549-560. [CrossRef]

53. Matadeen, R.; Hon, W.-C.; Heath, J.K.; Jones, Y.E.; Fuller, S. The dynamics of signal triggering in a gp130-receptor complex. Structure 2007, 15, 441-448. [CrossRef] [PubMed]

54. Stahl, N.; Farruggella, T.J.; Boulton, T.G.; Zhong, Z.; Darnell, J.J.; GD, Y. Choice of STATs and other substrates specified by modular tyrosine-based motifs in cytokine receptors. Science 1995, 267, 1349-1353. [CrossRef]

55. Gerhartz, C.; Heesel, B.; Sasse, J.; Hemmann, U.; Landgraf, C.; Schneider-Mergener, J.; Horn, F.; Heinrich, P.C.; Graeve, L. Differential activation of acute phase response factor/STAT3 and STAT1 via the cytoplasmic domain of the interleukin 6 signal transducer gp130. I. Definition of a novel phosphotyrosine motif mediating STAT1 activation. J. Biol. Chem. 1996, 271, 12991-12998. [CrossRef]

56. Heinrich, P.C.; Behrmann, I.; Haan, S.; Hermanns, H.M.; Muller-Newen, G.; Schaper, F. Principles of interleukin (IL)-6-type cytokine signalling and its regulation. Biochem. J. 2003, 374, 1-20. [CrossRef]

57. Fujitani, Y.; Hibi, M.; Fukada, T.; Takahashi-Tezuka, M.; Yoshida, H.; Yamaguchi, T.; Sugiyama, K.; Yamanaka, Y.; Nakajima, K.; Hirano, T. An alternative pathway for STAT activation that is mediated by the direct interaction between JAK and STAT. Oncogene 1997, 14, 751-761. [CrossRef]

58. Kaptein, A.; Paillard, V.; Saunders, M. Dominant negative stat3 mutant inhibits interleukin-6-induced Jak-STAT signal transduction. J. Biol. Chem. 1996, 271, 5961-5964. [CrossRef]

59. Gouilleux, F.; Wakao, H.; Mundt, M.; Groner, B. Prolactin induces phosphorylation of Tyr694 of Stat5 (MGF), a prerequisite for DNA binding and induction of transcription. EMBO J. 1994, 13, 4361-4369. [CrossRef]

60. Delgoffe, G.M.; Vignali, D.A. STAT heterodimers in immunity: A mixed message or a unique signal? JAKSTAT 2013, 2, e23060. [CrossRef]

61. Shuai, K.; Stark, G.R.; Kerr, I.M.; Darnell, J.E., Jr. A single phosphotyrosine residue of Stat91 required for gene activation by interferon-gamma. Science 1993, 261, 1744-1746. [CrossRef] [PubMed]

62. Babon, J.J.; Varghese, L.N.; Nicola, N.A. Inhibition of IL-6 family cytokines by SOCS3. Semin. Immunol. 2014, 26, 13-19. [CrossRef] [PubMed]

63. Yoshimura, A.; Naka, T.; Kubo, M. SOCS proteins, cytokine signalling and immune regulation. Nat. Rev. Immunol. 2007, 7, 454-465. [CrossRef] [PubMed]

64. Schmitz, J.; Weissenbach, M.; Haan, S.; Heinrich, P.C.; Schaper, F. SOCS3 exerts its inhibitory function on interleukin-6 signal transduction through the SHP2 recruitment site of gp130. J. Biol. Chem. 2000, 275, 12848-12856. [CrossRef] [PubMed]

65. Nicholson, S.E.; De Souza, D.; Fabri, L.J.; Corbin, J.; Willson, T.A.; Zhang, J.G.; Silva, A.; Asimakis, M.; Farley, A.; Nash, A.D.; et al. Suppressor of cytokine signaling-3 preferentially binds to the SHP-2-binding site on the shared cytokine receptor subunit gp130. Proc. Natl. Acad. Sci. USA 2000, 97, 6493-6498. [CrossRef] [PubMed]

66. Sasaki, A.; Yasukawa, H.; Suzuki, A.; Kamizono, S.; Syoda, T.; Kinjyo, I.; Sasaki, M.; Johnston, J.A.; Yoshimura, A. Cytokine-inducible SH2 protein-3 (CIS3/SOCS3) inhibits Janus tyrosine kinase by binding through the N-terminal kinase inhibitory region as well as SH2 domain. Genes Cells 1999, 4, 339-351. [CrossRef] 
67. Yasukawa, H.; Misawa, H.; Sakamoto, H.; Masuhara, M.; Sasaki, A.; Wakioka, T.; Ohtsuka, S.; Imaizumi, T.; Matsuda, T.; Ihle, J.N.; et al. The JAK-binding protein JAB inhibits Janus tyrosine kinase activity through binding in the activation loop. EMBO J. 1999, 18, 1309-1320. [CrossRef]

68. Kershaw, N.J.; Murphy, J.M.; Liau, N.P.; Varghese, L.N.; Laktyushin, A.; Whitlock, E.L.; Lucet, I.S.; Nicola, N.A.; Babon, J.J. SOCS3 binds specific receptor-JAK complexes to control cytokine signaling by direct kinase inhibition. Nat. Struct Mol. Biol. 2013, 20, 469-476. [CrossRef]

69. Kershaw, N.J.; Laktyushin, A.; Nicola, N.A.; Babon, J.J. Reconstruction of an active SOCS3-based E3 ubiquitin ligase complex in vitro: Identification of the active components and JAK2 and gp130 as substrates. Growth Factors 2014, 32, 1-10. [CrossRef]

70. Kamura, T.; Sato, S.; Haque, D.; Liu, L.; Kaelin, W.G., Jr.; Conaway, R.C.; Conaway, J.W. The Elongin BC complex interacts with the conserved SOCS-box motif present in members of the SOCS, ras, WD-40 repeat, and ankyrin repeat families. Genes Dev. 1998, 12, 3872-3881. [CrossRef]

71. Tebbutt, N.; Giraud, A.; Inglese, M.; Jenkins, B.; Waring, P.; Clay, F.; Malki, S.; Alderman, B.; Grail, D.; Hollande, F.; et al. Reciprocal regulation of gastrointestinal homeostasis by SHP2 and STAT-mediated trefoil gene activation in gp130 mutant mice. Nat. Med. 2002, 8, 1089-1097. [CrossRef] [PubMed]

72. Lehmann, U.; Schmitz, J.; Weissenbach, M.; Sobota, R.M.; Hortner, M.; Friederichs, K.; Behrmann, I.; Tsiaris, W.; Sasaki, A.; Schneider-Mergener, J.; et al. SHP2 and SOCS3 contribute to Tyr-759-dependent attenuation of interleukin-6 signaling through gp130. J. Biol. Chem. 2003, 278, 661-671. [CrossRef] [PubMed]

73. Dittrich, A.; Quaiser, T.; Khouri, C.; Gortz, D.; Monnigmann, M.; Schaper, F. Model-driven experimental analysis of the function of SHP-2 in IL-6-induced Jak/STAT signaling. Mol. Biosyst. 2012, 8, 2119-2134. [CrossRef] [PubMed]

74. Chung, C.D.; Liao, J.; Liu, B.; Rao, X.; Jay, P.; Berta, P.; Shuai, K. Specific inhibition of Stat3 signal transduction by PIAS3. Science 1997, 278, 1803-1805. [CrossRef]

75. Shuai, K.; Liu, B. Regulation of gene-activation pathways by PIAS proteins in the immune system. Nat. Rev. Immunol. 2005, 5, 593-605. [CrossRef]

76. Sun, Y.; Tokushige, K.; Isono, E.; Yamauchi, K.; Obata, H. Elevated serum interleukin-6 levels in patients with acute hepatitis. J. Clin. Immunol. 1992, 12, 197-200. [CrossRef]

77. Deviere, J.; Content, J.; Denys, C.; Vandenbussche, P.; Schandene, L.; Wybran, J.; Dupont, E. High interleukin-6 serum levels and increased production by leucocytes in alcoholic liver cirrhosis. Correlation with IgA serum levels and lymphokines production. Clin. Exp. Immunol. 1989, 77, 221-225.

78. Kakumu, S.; Shinagawa, T.; Ishikawa, T.; Yoshioka, K.; Wakita, T.; Ida, N. Interleukin 6 production by peripheral blood mononuclear cells in patients with chronic hepatitis B virus infection and primary biliary cirrhosis. Gastroenterol. Jpn. 1993, 28, 18-24. [CrossRef]

79. Shakiba, E.; Ramezani, M.; Sadeghi, M. Evaluation of serum interleukin-6 levels in hepatocellular carcinoma patients: A systematic review and meta-analysis. Clin. Exp. Hepatol. 2018, 4, 182-190. [CrossRef]

80. Shao, Y.Y.; Lin, H.; Li, Y.S.; Lee, Y.H.; Chen, H.M.; Cheng, A.L.; Hsu, C.H. High plasma interleukin-6 levels associated with poor prognosis of patients with advanced hepatocellular carcinoma. Jpn. J. Clin. Oncol. 2017, 47, 949-953. [CrossRef]

81. Naugler, W.E.; Sakurai, T.; Kim, S.; Maeda, S.; Kim, K.; Elsharkawy, A.M.; Karin, M. Gender disparity in liver cancer due to sex differences in MyD88-dependent IL-6 production. Science 2007, 317, 121-124. [CrossRef] [PubMed]

82. Wan, S.; Zhao, E.; Kryczek, I.; Vatan, L.; Sadovskaya, A.; Ludema, G.; Simeone, D.M.; Zou, W.; Welling, T.H. Tumor-associated macrophages produce interleukin 6 and signal via STAT3 to promote expansion of human hepatocellular carcinoma stem cells. Gastroenterology 2014, 147, 1393-1404. [CrossRef] [PubMed]

83. Zhou, T.Y.; Zhou, Y.L.; Qian, M.J.; Fang, Y.Z.; Ye, S.; Xin, W.X.; Yang, X.C.; Wu, H.H. Interleukin-6 induced by YAP in hepatocellular carcinoma cells recruits tumor-associated macrophages. J. Pharmacol. Sci. 2018, 138, 89-95. [CrossRef] [PubMed]

84. Giannitrapani, L.; Cervello, M.; Soresi, M.; Notarbartolo, M.; La Rosa, M.; Virruso, L.; D’Alessandro, N.; Montalto, G. Circulating IL-6 and sIL-6R in patients with hepatocellular carcinoma. Ann. N. Y. Acad. Sci. 2002, 963, 46-52. [CrossRef]

85. Bergmann, J.; Müller, M.; Baumann, N.; Reichert, M.; Heneweer, C.; Bolik, J.; Lücke, K.; Gruber, S.; Carambia, A.; Boretius, S.; et al. IL-6 trans-signaling is essential for the development of hepatocellular carcinoma in mice. Hepatology 2017, 65, 89-103. [CrossRef] 
86. Xiang, Z.L.; Zeng, Z.C.; Fan, J.; Tang, Z.Y.; Zeng, H.Y. Expression of connective tissue growth factor and interleukin-11 in intratumoral tissue is associated with poor survival after curative resection of hepatocellular carcinoma. Mol. Biol. Rep. 2012, 39, 6001-6006. [CrossRef]

87. Xiang, Z.L.; Zeng, Z.C.; Tang, Z.Y.; Fan, J.; He, J.; Zeng, H.Y.; Zhu, X.D. Potential prognostic biomarkers for bone metastasis from hepatocellular carcinoma. Oncologist 2011, 16, 1028-1039. [CrossRef]

88. Xiang, Z.L.; Zeng, Z.C.; Fan, J.; Wu, W.Z.; He, J.; Zeng, H.Y.; Tang, Z.Y. A clinicopathological model to predict bone metastasis in hepatocellular carcinoma. J. Cancer Res. Clin. Oncol. 2011, 137, 1791-1797. [CrossRef]

89. Yuan, J.-H.; Yang, F.; Wang, F.; Ma, J.-Z.; Guo, Y.-J.; Tao, Q.-F.; Liu, F.; Pan, W.; Wang, T.-T.; Zhou, C.-C.; et al. A Long Noncoding RNA Activated by TGF- $\beta$ Promotes the Invasion-Metastasis Cascade in Hepatocellular Carcinoma. Cancer Cell 2014, 25, 666-681. [CrossRef]

90. Zhang, L.; Niu, H.; Ma, J.; Yuan, B.Y.; Chen, Y.H.; Zhuang, Y.; Chen, G.W.; Zeng, Z.C.; Xiang, Z.L. The molecular mechanism of LncRNA34a-mediated regulation of bone metastasis in hepatocellular carcinoma. Mol. Cancer 2019, 18, 120. [CrossRef] [PubMed]

91. Zheng, H.; Yang, Y.; Han, J.; Jiang, W.H.; Chen, C.; Wang, M.C.; Gao, R.; Li, S.; Tian, T.; Wang, J.; et al. TMED3 promotes hepatocellular carcinoma progression via IL-11/STAT3 signaling. Sci. Rep. 2016, 6, 37070. [CrossRef]

92. Wang, D.; Zheng, X.; Fu, B.; Nian, Z.; Qian, Y.; Sun, R.; Tian, Z.; Wei, H. Hepatectomy promotes recurrence of liver cancer by enhancing IL-11-STAT3 signaling. EBioMedicine 2019, 46, 119-132. [CrossRef] [PubMed]

93. Zhang, J.F.; He, M.L.; Fu, W.M.; Wang, H.; Chen, L.Z.; Zhu, X.; Chen, Y.; Xie, D.; Lai, P.; Chen, G.; et al. Primate-specific microRNA-637 inhibits tumorigenesis in hepatocellular carcinoma by disrupting signal transducer and activator of transcription 3 signaling. Hepatology 2011, 54, 2137-2148. [CrossRef] [PubMed]

94. Luo, Q.; Zhang, Y.; Wang, N.; Jin, G.; Jin, H.; Gu, D.; Tao, X.; Huo, X.; Ge, T.; Cong, W.; et al. Leukemia inhibitory factor receptor is a novel immunomarker in distinction of well-differentiated HCC from dysplastic nodules. Oncotarget 2015, 6, 6989-6999. [CrossRef] [PubMed]

95. Okamura, Y.; Nomoto, S.; Kanda, M.; Li, Q.; Nishikawa, Y.; Sugimoto, H.; Kanazumi, N.; Takeda, S.; Nakao, A. Leukemia inhibitory factor receptor (LIFR) is detected as a novel suppressor gene of hepatocellular carcinoma using double-combination array. Cancer Lett. 2010, 289, 170-177. [CrossRef]

96. Luo, Q.; Wang, C.; Jin, G.; Gu, D.; Wang, N.; Song, J.; Jin, H.; Hu, F.; Zhang, Y.; Ge, T.; et al. LIFR functions as a metastasis suppressor in hepatocellular carcinoma by negatively regulating phosphoinositide 3-kinase/AKT pathway. Carcinogenesis 2015, 36, 1201-1212. [CrossRef]

97. Liang, H.; Block, T.M.; Wang, M.; Nefsky, B.; Long, R.; Hafner, J.; Mehta, A.S.; Marrero, J.; Gish, R.; Norton, P.A. Interleukin- 6 and oncostatin $\mathrm{M}$ are elevated in liver disease in conjunction with candidate hepatocellular carcinoma biomarker GP73. Cancer Biomark 2012, 11, 161-171. [CrossRef]

98. Rolvering, C.; Zimmer, A.D.; Kozar, I.; Hermanns, H.M.; Letellier, E.; Vallar, L.; Nazarov, P.V.; Nicot, N.; Ginolhac, A.; Haan, S.; et al. Crosstalk between different family members: IL27 recapitulates IFNgamma responses in HCC cells, but is inhibited by IL6-type cytokines. Biochim. Biophys. Acta Mol. Cell Res. 2017, 1864, 516-526. [CrossRef]

99. Song, Q.; Chen, X.; Hu, W.; Mei, G.; Yang, X.; Wu, H. Downregulation of Epstein-Barr virus-induced gene 3 is associated with poor prognosis of hepatocellular carcinoma after curative resection. Oncol. Lett. 2018, 15, 7751-7759. [CrossRef]

100. Li, B.; Su, H.; Cao, J.; Zhang, L. CXCL13 rather than IL-31 is a potential indicator in patients with hepatocellular carcinoma. Cytokine 2017, 89, 91-97. [CrossRef]

101. Schulze, K.; Nault, J.C.; Villanueva, A. Genetic profiling of hepatocellular carcinoma using next-generation sequencing. J. Hepatol. 2016, 65, 1031-1042. [CrossRef] [PubMed]

102. Ding, X.X.; Zhu, Q.G.; Zhang, S.M.; Guan, L.; Li, T.; Zhang, L.; Wang, S.Y.; Ren, W.L.; Chen, X.M.; Zhao, J.; et al. Precision medicine for hepatocellular carcinoma: Driver mutations and targeted therapy. Oncotarget 2017, 8, 55715-55730. [CrossRef] [PubMed]

103. Lee, J.S. The mutational landscape of hepatocellular carcinoma. Clin. Mol. Hepatol. 2015, 21, $220-229$. [CrossRef] [PubMed]

104. Kan, Z.; Zheng, H.; Liu, X.; Li, S.; Barber, T.D.; Gong, Z.; Gao, H.; Hao, K.; Willard, M.D.; Xu, J.; et al. Whole-genome sequencing identifies recurrent mutations in hepatocellular carcinoma. Genome Res. 2013, 23, 1422-1433. [CrossRef] [PubMed] 
105. Rebouissou, S.; Amessou, M.; Couchy, G.; Poussin, K.; Imbeaud, S.; Pilati, C.; Izard, T.; Balabaud, C.; Bioulac-Sage, P.; Zucman-Rossi, J. Frequent in-frame somatic deletions activate gp130 in inflammatory hepatocellular tumours. Nature 2009, 457, 200-204. [CrossRef]

106. Poussin, K.; Pilati, C.; Couchy, G.; Calderaro, J.; Bioulac-Sage, P.; Bacq, Y.; Paradis, V.; Leteurtre, E.; Sturm, N.; Ramos, J.; et al. Biochemical and functional analyses of gp130 mutants unveil JAK1 as a novel therapeutic target in human inflammatory hepatocellular adenoma. Oncoimmunology 2013, 2. [CrossRef]

107. Hatting, M.; Spannbauer, M.; Peng, J.; Al Masaoudi, M.; Sellge, G.; Nevzorova, Y.A.; Gassler, N.; Liedtke, C.; Cubero, F.J.; Trautwein, C. Lack of gp130 expression in hepatocytes attenuates tumor progression in the DEN model. Cell Death Dis 2015, 6, e1667. [CrossRef]

108. Galicia, J.; Tai, H.; Komatsu, Y.; Shimada, Y.; Akazawa, K.; Yoshie, H. Polymorphisms in the IL-6 receptor (IL-6R) gene: Strong evidence that serum levels of soluble IL-6R are genetically influenced. Genes Immun. 2004, 5, 513-516. [CrossRef]

109. Rafiq, S.; Frayling, T.; Murray, A.; Hurst, A.; Stevens, K.; Weedon, M.; Henley, W.; Ferrucci, L.; Bandinelli, S.; Corsi, A.M.; et al. A common variant of the interleukin 6 receptor (IL-6r) gene increases IL-6r and IL-6 levels, without other inflammatory effects. Genes Immun. 2007, 8, 552-559. [CrossRef]

110. Garbers, C.; Monhasery, N.; Aparicio-Siegmund, S.; Lokau, J.; Baran, P.; Nowell, M.A.; Jones, S.A.; Rose-John, S.; Scheller, J. The Interleukin-6 Receptor Asp358Ala Single Nucleotide Polymorphism rs2228145 Confers Increased Proteolytic Conversion Rates by ADAM Proteases. Biochim. Biophys. Acta 2014, 1842, 1485-1494. [CrossRef]

111. Ferreira, R.; Freitag, D.; Cutler, A.; Howson, J.M.; Rainbow, D.; Smyth, D.; Kaptoge, S.; Clarke, P.; Boreham, C.; Coulson, R.; et al. Functional IL6R 358Ala Allele Impairs Classical IL-6 Receptor Signaling and Influences Risk of Diverse Inflammatory Diseases. PLoS Genet. 2013, 9, e1003444. [CrossRef] [PubMed]

112. Agthe, M.; Brugge, J.; Garbers, Y.; Wandel, M.; Kespohl, B.; Arnold, P.; Flynn, C.M.; Lokau, J.; Aparicio-Siegmund, S.; Bretscher, C.; et al. Mutations in Craniosynostosis Patients Cause Defective Interleukin-11 Receptor Maturation and Drive Craniosynostosis-like Disease in Mice. Cell Rep. 2018, 25, 10-18 e15. [CrossRef] [PubMed]

113. Keupp, K.; Li, Y.; Vargel, I.; Hoischen, A.; Richardson, R.; Neveling, K.; Alanay, Y.; Uz, E.; Elcioğlu, N.; Rachwalski, M.; et al. Mutations in the interleukin receptor IL11RA cause autosomal recessive Crouzon-like craniosynostosis. Mol. Genet. Genomic Med. 2013, 1, 223-237. [CrossRef] [PubMed]

114. Nieminen, P.; Morgan, N.; Fenwick, A.; Parmanen, S.; Veistinen, L.; Mikkola, M.; van der Spek, P.; Giraud, A.; Judd, L.; Arte, S.; et al. Inactivation of IL11 signaling causes craniosynostosis, delayed tooth eruption, and supernumerary teeth. Am. J. Hum. Genet. 2011, 89, 67-81. [CrossRef] [PubMed]

115. Xie, H.J.; Bae, H.J.; Noh, J.H.; Eun, J.W.; Kim, J.K.; Jung, K.H.; Ryu, J.C.; Ahn, Y.M.; Kim, S.Y.; Lee, S.H.; et al. Mutational analysis of JAK1 gene in human hepatocellular carcinoma. Neoplasma 2009, 56, 136-140. [CrossRef] [PubMed]

116. Yang, S.; Luo, C.; Gu, Q.; Xu, Q.; Wang, G.; Sun, H.; Qian, Z.; Tan, Y.; Qin, Y.; Shen, Y.; et al. Activating JAK1 mutation may predict the sensitivity of JAK-STAT inhibition in hepatocellular carcinoma. Oncotarget 2016, 7, 5461-5469. [CrossRef] [PubMed]

117. Ungureanu, D.; Wu, J.; Pekkala, T.; Niranjan, Y.; Young, C.; Jensen, O.N.; Xu, C.F.; Neubert, T.A.; Skoda, R.C.; Hubbard, S.R.; et al. The pseudokinase domain of JAK2 is a dual-specificity protein kinase that negatively regulates cytokine signaling. Nat. Struct. Mol. Biol. 2011, 18, 971-976. [CrossRef] [PubMed]

118. He, G.; Yu, G.Y.; Temkin, V.; Ogata, H.; Kuntzen, C.; Sakurai, T.; Sieghart, W.; Peck-Radosavljevic, M.; Leffert, H.L.; Karin, M. Hepatocyte IKKbeta/NF-kappaB inhibits tumor promotion and progression by preventing oxidative stress-driven STAT3 activation. Cancer Cell 2010, 17, 286-297. [CrossRef]

119. Calvisi, D.F.; Ladu, S.; Gorden, A.; Farina, M.; Conner, E.A.; Lee, J.S.; Factor, V.M.; Thorgeirsson, S.S. Ubiquitous activation of Ras and Jak/Stat pathways in human HCC. Gastroenterology 2006, 130, 1117-1128. [CrossRef]

120. Pilati, C.; Amessou, M.; Bihl, M.; Balabaud, C.; Nhieu, J.; Paradis, V.; Nault, J.; Izard, T.; Bioulac-Sage, P.; Couchy, G.; et al. Somatic mutations activating STAT3 in human inflammatory hepatocellular adenomas. J. Exp. Med. 2011, 208, 1359-1366. [CrossRef]

121. Pilati, C.; Zucman-Rossi, J. Mutations leading to constitutive active gp130/JAK1/STAT3 pathway. Cytokine Growth Factor Rev. 2015, 26, 499-506. [CrossRef] 
122. Zhang, J.; Li, Z.; Liu, L.; Wang, Q.; Li, S.; Chen, D.; Hu, Z.; Yu, T.; Ding, J.; Li, J.; et al. Long noncoding RNA TSLNC8 is a tumor suppressor that inactivates the interleukin-6/STAT3 signaling pathway. Hepatology 2018, 67, 171-187. [CrossRef]

123. Chen, G.; Wang, H.; Xie, S.; Ma, J.; Wang, G. STAT1 negatively regulates hepatocellular carcinoma cell proliferation. Oncol. Rep. 2013, 29, 2303-2310. [CrossRef]

124. Chen, J.; Wang, H.; Wang, J.; Huang, S.; Zhang, W. STAT1 inhibits human hepatocellular carcinoma cell growth through induction of p53 and Fbxw7. Cancer Cell Int. 2015, 15, 111. [CrossRef]

125. Ma, B.; Chen, K.; Liu, P.; Li, M.; Liu, J.; Sideras, K.; Sprengers, D.; Biermann, K.; Wang, W.; Ijzermans, J.N.M.; et al. Dichotomal functions of phosphorylated and unphosphorylated STAT1 in hepatocellular carcinoma. J. Mol. Med. (Berl.) 2019, 97, 77-88. [CrossRef]

126. Hoan, N.X.; Van Tong, H.; Giang, D.P.; Cuong, B.K.; Toan, N.L.; Wedemeyer, H.; Bock, C.T.; Kremsner, P.G.; Song, L.H.; Velavan, T.P. SOCS3 genetic variants and promoter hypermethylation in patients with chronic hepatitis B. Oncotarget 2017, 8, 17127-17139. [CrossRef]

127. Zhang, X.; You, Q.; Zhang, X.; Chen, X. SOCS3 Methylation Predicts a Poor Prognosis in HBV Infection-Related Hepatocellular Carcinoma. Int J. Mol. Sci. 2015, 16, 22662-22675. [CrossRef]

128. Jiang, B.G.; Wang, N.; Huang, J.; Yang, Y.; Sun, L.L.; Pan, Z.Y.; Zhou, W.P. Tumor SOCS3 methylation status predicts the treatment response to TACE and prognosis in HCC patients. Oncotarget 2017, 8, 28621-28627. [CrossRef]

129. Riehle, K.J.; Campbell, J.S.; McMahan, R.S.; Johnson, M.M.; Beyer, R.P.; Bammler, T.K.; Fausto, N. Regulation of liver regeneration and hepatocarcinogenesis by suppressor of cytokine signaling 3. J. Exp. Med. 2008, 205, 91-103. [CrossRef]

130. Daher, S.; Massarwa, M.; Benson, A.A.; Khoury, T. Current and Future Treatment of Hepatocellular Carcinoma: An Updated Comprehensive Review. J. Clin. Transl Hepatol. 2018, 6, 69-78. [CrossRef]

131. Tian, G.; Yang, S.; Yuan, J.; Threapleton, D.; Zhao, Q.; Chen, F.; Cao, H.; Jiang, T.; Li, L. Comparative efficacy of treatment strategies for hepatocellular carcinoma: Systematic review and network meta-analysis. BMJ Open 2018, 8, e021269. [CrossRef]

132. Marrero, J.A.; Kulik, L.M.; Sirlin, C.B.; Zhu, A.X.; Finn, R.S.; Abecassis, M.M.; Roberts, L.R.; Heimbach, J.K. Diagnosis, Staging, and Management of Hepatocellular Carcinoma: 2018 Practice Guidance by the American Association for the Study of Liver Diseases. Hepatology 2018, 68, 723-750. [CrossRef]

133. Lencioni, R.; de Baere, T.; Soulen, M.C.; Rilling, W.S.; Geschwind, J.F. Lipiodol transarterial chemoembolization for hepatocellular carcinoma: A systematic review of efficacy and safety data. Hepatology 2016, 64, 106-116. [CrossRef]

134. Loosen, S.H.; Schulze-Hagen, M.; Leyh, C.; Benz, F.; Vucur, M.; Kuhl, C.; Trautwein, C.; Tacke, F.; Bruners, P.; Roderburg, C.; et al. IL-6 and IL-8 Serum Levels Predict Tumor Response and Overall Survival after TACE for Primary and Secondary Hepatic Malignancies. Int. J. Mol. Sci. 2018, 19, 1766. [CrossRef]

135. Garbers, C.; Heink, S.; Korn, T.; Rose-John, S. Interleukin-6: Designing specific therapeutics for a complex cytokine. Nat. Rev. Drug Discov. 2018, 17, 395-412. [CrossRef]

136. Garbers, C.; Aparicio-Siegmund, S.; Rose-John, S. The IL-6/gp130/STAT3 signaling axis: Recent advances towards specific inhibition. Curr. Opin. Immunol. 2015, 34, 75-82. [CrossRef]

137. Llovet, J.M.; Ricci, S.; Mazzaferro, V.; Hilgard, P.; Gane, E.; Blanc, J.F.; de Oliveira, A.C.; Santoro, A.; Raoul, J.L.; Forner, A.; et al. Sorafenib in advanced hepatocellular carcinoma. N. Engl. J. Med. 2008, 359, 378-390. [CrossRef] [PubMed]

138. Kudo, M.; Finn, R.S.; Qin, S.; Han, K.H.; Ikeda, K.; Piscaglia, F.; Baron, A.; Park, J.W.; Han, G.; Jassem, J.; et al. Lenvatinib versus sorafenib in first-line treatment of patients with unresectable hepatocellular carcinoma: A randomised phase 3 non-inferiority trial. Lancet 2018, 391, 1163-1173. [CrossRef]

139. Schwartz, D.M.; Kanno, Y.; Villarino, A.; Ward, M.; Gadina, M.; O'Shea, J.J. JAK inhibition as a therapeutic strategy for immune and inflammatory diseases. Nat. Rev. Drug Discov. 2017, 16, 843-862. [CrossRef]

140. Wilson, G.S.; Tian, A.; Hebbard, L.; Duan, W.; George, J.; Li, X.; Qiao, L. Tumoricidal effects of the JAK inhibitor Ruxolitinib (INC424) on hepatocellular carcinoma in vitro. Cancer Lett. 2013, 341, 224-230. [CrossRef]

141. Ma, H.; Yan, D.; Wang, Y.; Shi, W.; Liu, T.; Zhao, C.; Huo, S.; Duan, J.; Tao, J.; Zhai, M.; et al. Bazedoxifene exhibits growth suppressive activity by targeting interleukin-6/glycoprotein 130/signal transducer and activator of transcription 3 signaling in hepatocellular carcinoma. Cancer Sci. 2019, 110, 950-961. [CrossRef] [PubMed] 
142. Saad, M.I.; Rose-John, S.; Jenkins, B.J. ADAM17: An Emerging Therapeutic Target for Lung Cancer. Cancers 2019, 11, 1218. [CrossRef] [PubMed]

143. Saad, M.I.; Alhayyani, S.; McLeod, L.; Yu, L.; Alanazi, M.; Deswaerte, V.; Tang, K.; Jarde, T.; Smith, J.A.; Prodanovic, Z.; et al. ADAM17 selectively activates the IL-6 trans-signaling/ERK MAPK axis in KRAS-addicted lung cancer. EMBO Mol. Med. 2019, 11. [CrossRef] [PubMed]

144. Wang, R.; Li, Y.; Tsung, A.; Huang, H.; Du, Q.; Yang, M.; Deng, M.; Xiong, S.; Wang, X.; Zhang, L.; et al. iNOS promotes CD24(+)CD133(+) liver cancer stem cell phenotype through a TACE/ADAM17-dependent Notch signaling pathway. Proc. Natl. Acad. Sci. USA 2018, 115, E10127-E10136. [CrossRef]

(C) 2019 by the authors. Licensee MDPI, Basel, Switzerland. This article is an open access article distributed under the terms and conditions of the Creative Commons Attribution (CC BY) license (http://creativecommons.org/licenses/by/4.0/). 